\title{
Semiformal Organizations and Control During the COVID-19 Crisis in China
}

\author{
Shanhe Jiang ${ }^{1} \cdot$ Dawei Zhang ${ }^{2}$ (D) Darrell D. Irwin ${ }^{3}$ \\ Received: 6 July 2020 / Accepted: 16 October 2020 / Published online: 30 October 2020 \\ (C) Springer Nature B.V. 2020
}

\begin{abstract}
Scholars often compare China and Western societies in terms of dichotomous forms of control-formal and informal. Recent research indicates a nuanced form of social control-semiformal. Using a survey data collected during the 2020 COVID-19 pandemic in China, this study investigated the prevalence and importance of semiformal organizations, formal organizations, and informal groups participating in social control and social service and the predictors of the perceived importance of these three forms of social control mechanisms. Findings from this study revealed that formal organizations, the semiformal organizations, and informal groups all participated in community control and service. Semiformal organizations had the highest level of participation. This study found that education and age are the two major predictors of the views on the importance of formal, informal, and semiformal control and control mechanisms.
\end{abstract}

Keywords COVID-19 · Semiformal organizations · Semiformal control · Formal control · Informal control $\cdot$ China

All nations need social control, but forms of control vary from country to country. Scholars used to compare China and Western societies, particularly the USA, in terms of social control

Dawei Zhang

zhangsir0619@sina.com

Shanhe Jiang

fx6954@wayne.edu

Darrell D. Irwin

darrell.irwin@uconn.edu

1 Department of Criminology and Criminal Justice, Wayne State University, 656 W Kirby St., Detroit, MI 48202, USA

2 Central China Normal University, 152 Luoyu Road, Wuhan 430079, China

3 University of Connecticut, Manchester Hall, Room 325, 344 Mansfield Rd., Unit 1068, Storrs, CT 06269, USA 
mechanisms and commonly believe that China is more likely to implement informal control while the USA is more in favor of formal control (Chen 2004; Friday 1998; Jiang et al. 2010a; Jiang et al. 2010b; Rojek 2001). Recent research starts to pay attention to another form of social control-semiformal. This article focuses on the emergent semiformal control (Jiang et al. 2019) in the lockdown, or Class 1 Response to Public Health Emergency, that was declared to confront the COVID-19 pandemic in early 2020 in Wuhan, China.

Built on previous studies, Jiang et al. (2019) set out the semiformal control concept in Chinese society. They then used qualitative cases to demonstrate the prevalence of semiformal organizations and semiformal control. They also discussed the reasons why semiformal organizations and semiformal control have existed in China. The Jiang et al. (2019) article also proposed the possible outcomes of semiformal control and their measurements and mediating factors between forms of social control and outcome such as the impact of supervisors, the level of integration of the supervisor and supervisee, and collective efficacy of supervisees.

Jiang et al. (2019) are the first scholars to systematically elaborate the semiformal control concept, its prevalence, predictors, and measurement of its possible impact in criminology and criminal justice. Among the earliest studies of semiformal control, there are a few quantitative studies examining the effects of semiformal control on crime (Jiang et al. 2013; Zhang et al. 1996; Zhang et al. 2007) or comparing the forms of formal and semiformal control in corrections (Jiang et al. 2015). Historian P. C. C. Huang also made a contribution to studies on the use of semiformal governance for dispute resolution in land ownership, employment, marital dissolution, and in a wide range of civil litigation (1993a, 1993b, 2010). However, much more could be understood as to the importance of semiformal control and semiformal organization from focused empirical research. This study was undertaken to fill that void. By presenting an empirical examination of survey data on the range of controls used to stem the 2020 COVID-19 pandemic in China, this study aims to investigate (1) the prevalence of semiformal organizations participating in social control and social service, relative to formal organizations and informal groups; (2) the importance of semiformal organizations in social control and social service, compared to formal organizations and informal groups; and (3) the predictors of different forms of social control.

The approach to this analysis begins with a brief introduction about the outbreak of COVID-19 in China. The next section has a short review of the three forms of social control and possible predictors of the views of the forms of social control and control mechanisms. Sections on data, measures of dependent and independent variables, and findings follow. Finally, a summary and conclusion section completes the paper.

\section{The Outbreak of COVID-19 and Measures}

Since early January 2020, news of COVID-19, a potentially deadly disease, had gradually circulated beyond a few medical doctors to the public via mass media and social media (Han 2020). On January 20, 2020, Dr. Zhong Nanshan, the director of the experts group of the National Health Commission of the People's Republic of China, first announced that COVID19 had the risk of human-to-human transmission. He also recommended that Wuhan citizens should not leave the city and non-Wuhan residents should not enter Wuhan, the capital city of Hubei Province (Han 2020). On January 22, Hubei Province launched a Class 2 Response to Public Health Emergency. The following day on January 23, 2020, Wuhan issued a lockdown 
order. On January 24, Hubei invoked a Class 1 Response to Public Health Emergency (Han 2020). Under the lockdown order and Class I Response, the city's public transportation services including bus, metro, and ferry services were suspended. The city's airport and railway stations were also suspended except for exceptional circumstances. Residents were first advised and then ordered to shelter in place and only allowed to leave their residence for essential activities (China CDC 2020; Hubei.gov 2020). During the period of lockdown, the local community played an essential role in food supplies, health screening, collecting and distributing the COVID-19-related information, supplying personal protective gear, setting up checkpoints to monitor people who enter and exit communities, made drug purchases for those who faced difficulties obtaining medicines on their own, and carried out duties of community sanitization.

Other major cities and provinces quickly followed suit to launch a lockdown or issue a Class 1 Response to Public Health Emergency. By January 29, all 31 provinces (or equivalents) in mainland China had launched a Class 1 Response (Caixin 2020) and followed similar measures as Wuhan and the other cities in Hubei Province. Starting on March 13, cities in Hubei Province, except for Wuhan, rescinded strict travel restrictions, and the citizens' daily lives began to gradually return to normal. On April 8, Wuhan lifted its lockdown, being the last city in Hubei and China to remove such strict controls (Mao et al. 2020).

\section{Three Forms of Social Control, Their Importance, and Predictors}

Traditional classification of social control is dichotomous: formal and informal (Black 1976, 1993; Rose and Clear 1998). Formal social control is a control imposed by law and implemented by government or government agencies such as courts, police, and prisons, while informal social control is a control carried out by informal groups such as neighborhood watches and kin mediation based on moral rules (Huang 1993a; Jiang et al. 2007; Liu et al. 2001; Rosenbaum 1988). However, when this dichotomous classification of social control is applied to China, it overlooks an important form of social control-semiformal social control (Huang 1993a, 1993b, 2010; Jiang 2014; Jiang et al. 2015; Jiang et al. 2019).

During the early period of China's economic reform, researcher Ronald Troyer visited China five times from 1982 to 1987 to observe the Chinese responses to crime and deviant behavior. His visitations, observations, and conversations with Chinese officials and citizens, along with his examination of news media and academic literature review impressed upon him that two grassroots organizations - the residents' committee and the residents' groups - played an important role in social and crime control. He noted, however, that "they are not voluntary association in the U.S. sense; they are government organized and controlled entities" (Troyer 1989: p. 27). Although Troyer did not use the terms such as semiformal governance or control, he implied that these grassroots organizations are different from those informal groups and informal control in the USA.

In their article published in 1996, Zhang and his associates examined the importance of Tiao-jie and Bang-jiao in social control and crime prevention in China. According to Xiong (1999), Tiao-jie is a form of mediating disputes that is carried out by the people's mediation committee, which is under the leadership of the residents' committee in urban areas and of the village committee in rural areas. Another form, "Bang-jiao means assisting, helping, guiding, and directing offenders, especially juvenile offenders" (Zhang et al. 1996: p. 208). Both Tiaojie and Bang-jiao groups are neither completely formal nor informal control devices. They are 
mass-roots organizations, both imposed and heavily influenced by the government, with rules for social behavior.

Chen (2004) compared and contrasted Chinese and Western social and legal control. He found that "some informal institutions such as neighborhood committees do not form a part of the formal criminal justice system, yet they are established based on certain legal regulations and often are trained by local justice organs or police" (Chen 2004: p. 524). Thus, informal groups or organizations such as neighborhood committees in China are "quasi-formal."

Huang (2008) reported similar forms of social control and control mechanism. Using his archival research of documents from different periods of history in China, Huang (2008) revealed a form of governance in dispute resolution which differs from that in the West; he called it semiformal governance. Through his archival research of the Qing Dynasty's (16441911) approach to civil justice or minor matters, Huang (2008) found that many small disputes such as arguments over land, debt, inheritance, and marriage were usually resolved by interventions by the local community or kin mediation. For minor matters, only when disputes could not be resolved by the local community, the court got involved. Xiangbao (乡保) played an important role in handling local issues and was the liaison between the court and the community mediation. Xiangbao was an unsalaried quasi-official recommended by the local community and confirmed by the state. The court heavily relied on Xiangbao's work for its decisions on dispute cases and preferred to use informal and semiformal processes to resolve them. The widespread use of an unsalaried quasi-official in the process of disputes is semiformal governance.

Huang (2008) also found that the semiformal governance in the late Qing not only existed in civil justice but also was frequently utilized in tax administration and educational administration. In fact, semiformal governance continued to exist in the Republic period (19111949) and the People's Republic of China (1949-present) of today.

In their test of the generalizability of social disorganization theory, Jiang et al. (2013) also used social and crime control carried out by residents' committees as semiformal control and examined its impact on crime. Based on the survey data, they revealed that semiformal control did decrease the perceived neighborhood property crime in Guangzhou, China.

In 2014, Jiang reviewed the conceptual and empirical articles which pertain to the forms of social and crime control and stated that semiformal control is one of the Chinese characteristics in social and crime control (Jiang 2014). In 2015, Jiang and his associates expanded the review of the forms of social and crime control and concurred with Huang (2008) that traditional research of the forms of formal and informal social and crime control overlooked an important form of control-semiformal. Semiformal control is the integration of formal and informal controls (Huang 1993a, 1993b, 2010; Jiang et al. 2015). Semiformal control positions features underlying formal control and informal control but uniquely has features neither found in informal nor formal control. Control carried out by semiformal organizations is the core part of semiformal control. According to Jiang et al. (2015), "semiformal organizations integrate formal and informal organizational features; they are grassroots organizations but are marked by the government; they are nongovernmental organizations but have official power and responsibilities; they are a bridge between the state and society.” (p. 290). Jiang et al.'s study (2015) not only described the semiformal control features of Chinese community corrections but also empirically compared and contrasted correctional staff workers (representing formal control) and community committee members (representing semiformal control) in terms of individual characteristics, views of the criminal justice system, and the supervision strategies. 
Encompassing a number of direct observations and studies, Jiang et al. (2019) summarized three forms of social control: formal, informal, and semiformal. Formal social control is a "control imposed by law and/or implemented by official controlling organizations" (Jiang et al. 2007, p. 262). Policing and corrections are typical examples of formal social and crime control. Informal social control is a "control carried out by unofficial controlling groups based on moral rules" (Jiang et al. 2007, p. 262). Shaming by family members and neighbors is an example of informal social control. Collective efficacy proposed by Sampson et al. (1997) is another example of informal social control acting to mediate social problems.

Semiformal social control is the mix of formal and informal controls (Huang 1993a, 1993b, 2010). Based on both controlling actor and rules of control, Jiang et al. (2019) defined semiformal control as controlling action that is carried out by (1) semiformal organizations based on sentiment, reason, and law, and (2) government agencies or other formal organizations based on sentiment and reason. Although government agencies and other formal organizations may use sentiment and reason to help their controlling action, their primary or basic action rules are laws, policies, and formal regulations. In addition, using Jiang et al.'s (2019) definition would be difficult to classify or decide whether government agencies as formal or semiformal. Thus, the current study uses controlling actors as a criterion and defines semiformal control as controlling action that is implemented by semiformal organizations.

Semiformal social control can be manifested in diverse ways in China. For example, when a community corrections group, consisted of local justice officers, community committee members, volunteers, and family members, employs the law and regulations to re-educate and reform an offender, semiformal control occurs (Jiang et al. 2015; Jiang et al. 2019). When the mediation team within a community or a grid, which is usually composed of the Communist Party organization building, resident's committee administration, and residential volunteers, resolves disputes between residents based on laws and local norms (Tang 2020), semiformal control occurs. More broadly speaking, when social or crime control is carried out by semiformal organizations, semiformal social control occurs (Jiang et al. 2015; Jiang et al. 2019). Communities (shequ) in China are large and widespread semiformal organizations. Every local residential community is administered by a resident's committee in urban areas while it is managed by a village committee in rural areas (Jiang et al. 2015). Accordingly, the last type of semiformal control is the most commonly used in China's social and crime control (Jiang et al. 2019).

Thus, a body of literature has emerged regarding the important role that semiformal organizations play in China's social control and social services. Important semiformal organizations such as residents' committees and village committees bridge government and individual citizens. The government provides services to citizens and supervises citizens through community committees. Semiformal organizations and controls make it possible for the Chinese government to effectively deal with emergencies or crises such as the COVID-19 outbreak. However, there is limited quantitative research on the investigation of the prevalence and importance of semiformal organizations in social control and service. This study was undertaken as an academic project to glean data on the use of social control during the COVID-19 pandemic. The study also intended to quantitatively explore what stated and unstated factors explain the perceived importance of control. This research formulates the first effort to search for the predictors of the importance views. Since there were no clear theoretical guidelines for the predictor selection, the previous literature on the importance of social control forms were used for the variable selection employed in this study.

he variables gender, age, and education are often included as demographic characteristics in the extant studies (Jiang et al. 2010a; Jiang et al. 2010b; Jiang et al. 2012; Jiang et al. 2014; 
Lambert et al. 2012a; Lambert et al. 2012b). Following suit, this study also included them. The study additionally included another characteristic - political affiliation - whether the respondent is a Communist Party member. This variable is essential since the party membership is expected to be in favor of formal control mechanisms such as government agencies/officers and the police. Living area is another commonly examined correlate of the views of forms of social and crime control (Jiang et al. 2007; Jiang and Lambert 2009; Jiang et al. 2012; Jiang et al. 2014). Since the outbreak of COVID-19 in Wuhan, the virus subsequently spread across China and around the world at different points. Thus, this study also included two dummy variables (Wuhan; Hubei) to examine whether Wuhan and Hubei differed from other areas in China in the views of three forms of social control and social service.

As for gender, in the West, particularly in the USA, women are encouraged to think independently. Due to different socializations, especially during childhood, women are more likely to use a "care voice" reasoning for their response to many social and criminal justice issues, while men are more likely to use a "justice voice" reasoning to express their opinions (Gilligan 1982). Women are often linked to an empathic, caring attitude toward criminal justice issues, while men are more likely to be impartial and justice oriented (Lambert et al. 2007). In China, women occupy different cultural, political, and social environments. On the one hand, when China progressively becomes modernized, women receive more education and become more economically independent, and they are encouraged to think more independently. On the other hand, patriarchal tradition, collectivism, and the one-party political system all encourage, promote, or even pressure different genders to think similarly (Lambert et al. 2007). It is uncertain whether gender affects the views of different forms of social control and social service. In the past studies about the views of formal and informal control in China, results are mixed. Most studies did not find an association between gender and the views of forms of social control. When Lambert et al. (2007) examined whether gender differed in 15 statements (some of them measured formal or informal control), gender did show differences in some statements but not for others. Jiang et al. (2010a) reported men were more likely than women to believe that formal control such as police, courts, and incarceration is deterrent to crime. However, the sample used in Jiang, Lambert, and Jenkins' analysis included respondents from China and the USA. Clearly, more research on gender and the views of forms of social control is warranted.

Age is commonly believed to be positively associated with the views of social control and social service. In other words, younger people are less likely to value social control than their older counterparts are. Two possible reasons behind this assumption are that younger people are freer from constraints, and younger people are more likely to self-support and be self-sufficient. Three studies quantitatively examined whether age is associated with the views of informal and formal social control in China. Two studies (Jiang et al. 2014; Jiang et al. 2010b) revealed no relationship existed between them. One (Jiang et al. 2010a) reported a positive relationship. When a specific formal agency was evaluated, age sometimes was found to be related to the views of formal control or formal control organizations. For example, Sun et al. (2017) found that age was positively related to perceived police legitimacy and cooperation with police. Inconsistent findings in the previous studies invite more research on age as a variable.

Education is also used to predict the views of formal and informal social control but in the lesser degree, relative to gender and age. Generally, education leads to more critical and independent thinking that in turn results in the less favorable assessment of the importance of formal organizations in social control and more favorable attitudes toward the importance of informal groups in social control. Two empirical studies reported mixed results concerning 
informal social control. One study conducted by Jiang et al. (2010b) found that education was not associated with the perceived importance of informal control in neighborhoods in Guangzhou, China. Another study conducted in Hubei by Jiang and Lambert (2009) reported that more educated people perceived more importance of informal groups in social control but perceived less importance of formal organizations.

During the COVID-19 crisis, governments in each nation have played a leading role in social control and social services. At the community level, the importance of government in social control and social services may vary from society to society. Political affiliation could affect the perceived importance of government and other control mechanisms in China. Furthermore, Chinese Communist Party members may have more favorable ranking of the importance of formal control mechanisms such as government agencies and police than non-party members may. In contrast, non-party members may believe that semiformal organizations such as residents' committee/village committee and volunteers are more important in social control and service at the community level. Thus, this study included party affiliation to examine whether the party membership affects respondents' views of forms of social control and service mechanisms.

People who grow up in rural areas are socialized differently from those who grow up in urban areas. The cultures of rural areas have more traditional values with more personal interactions and thus are more cohesive than the culture of large urban areas. People who grow up in rural areas are more likely to use and believe in informal mechanisms such as family, neighborhood, and peers in maintaining community order and providing or obtaining mutual support. Jiang et al. (2007) found that compared to people from urban areas, people from rural areas were more likely to rank the importance of informal control in crime prevention higher and the importance of formal control lower in China. However, Jiang and Lambert (2009) did not find the connection between living areas and ranking of the importance of formal and informal mechanisms in social control or crime prevention. This study further examined whether urbanization affects people's views of the importance of forms of control mechanisms in social control and services. Our research anticipated that, relative to respondents from urban areas, respondents from rural areas rank the importance of community organizations and informal groups higher in terms of social control and service. For the importance of formal organizations in social control and service, the urbanization impact may be murkier. People from rural areas have more traditional values and may have high trust and confidence in government (Irwin et al. 2016). They may be more likely or equally likely to value the importance of government agencies in social control and service relative to their urban counterparts.

The last two variables included in this study are based on the unique situation of the COVID19 crisis. COVID-19 was first reported in Wuhan and then spread throughout China and the world. Wuhan experienced the most severe public health crisis in China. Accordingly, social control and service needs in Wuhan and surrounding areas in Hubei may also differ. People from different areas may also view the role of government agencies, police, community, volunteers, and regular citizens in maintaining community order and providing service differently. Thus, this study created two dummy variables to see whether people from Wuhan, Hubei, outside Wuhan, and other provinces have different views of the importance of three forms of social control.

\section{Methods}

Based on the reported COVID-19 cases in China, there is clear ranking order of severity of the outbreak among these three areas: Wuhan, the capital of Hubei Province; Hubei excluding 
Wuhan; and other 30 provinces. The research team planned to collect data from approximately 200 people from each of the three regions.

Semiformal control and semiformal organizations are prevalent and play an important role in China's governance including social control and social service (Jiang et al. 2019). To quantitatively verify the prevalence and the importance of semiformal control and semiformal organizations, the research team in China designed the survey instrument and conducted the surveys. The questionnaire used in the survey was designed based on the semiformal control theory proposed by Jiang et al. (2019) and additional literature on formal and informal control. The first questionnaire draft was completed in March 2020 and then pretested in Hubei and eight other provinces at the end of March. In the early April, the revised questionnaire was pretested again in Hubei including Wuhan.

Considering memory will be gradually lost with time, the survey organizer in China recruited 48 interviewers from Wuhan, Hubei, and other regions to speed up the pace of the surveys. These interviewers were a mixture of current graduate students or graduates from the organizer's school and had experience in conducting previous surveys. All the interviewers were trained on how to conduct this survey in early April.

The survey began on April 3 and ended on April 18, 2020. During this period, although China lifted its lockdown orders in all areas except in Wuhan, many places still had restrictions on travel or person to person interactions. Thus, to collect valid data and improve the response rate, two data collection methods were employed. One method was to send the survey instrument to the interviewees via the Chinese social media WeChat app or other digital portals where respondents were to answer the questions by themselves. Using this method, the interviewers were required to be available to answer any questions when a respondent was completing the questionnaire. Doing so aimed at helping improve the completion rate for the entire survey instrument as well as each individual question. The second survey method used to collect data was via an online platform such as Zoom or WeChat or in face-to-face interviews. Using this method, the interviewers asked questions and recorded the interviewees' responses. All the respondents were informed (1) who the survey team were; (2) the survey participation was voluntary; and (3) the data from the survey would be confidential. Through this process, respondents were assured if the collected data are used for publications or reports, no individual respondents would be identified. Seven hundred questionnaires (online or in print) were distributed, and 632 valid questionnaires were used in this study. Successful response rate was slightly more than $90 \%$.

\section{Three Forms of Social Control, Dependent Variables, and Measurement}

One of the survey's purposes was to collect data on the prevalence of formal, informal, and semiformal control or organizations in maintaining community order and providing service during the COVID-19 lockdown. Government agencies or officials and community police or police officers are the indicators of formal control mechanisms. Volunteers and regular citizens are the indicators of informal control groups or individuals. Community committees or committee members are the indicators of semiformal control mechanisms. Thus, questions pertaining to the prevalence of three forms of control ask whether each of these actors participated in community control and service during the lockdown period. Related to the prevalence, the respondents were also asked to judge how important each of these organizations or their representatives was in six essential community control and service activities 
during the COVID-19 lockdown: checkpoint inspection, health screening, food supplies, drug supplies, sanitization, and information distribution. Importance here refers to an appraisal of the level of involvement of a given actor. The response categories for these questions were not important at all $(=1)$, not important $(=2)$, between not important and important $(=3)$, important (=4), and very important $(=5)$. The score summation of these six activities formed the five dependent variables for five-control-service mechanisms: community, government, police, volunteer, and citizen.

\section{Independent Variables}

Independent variables in this study refer to those predictors of the views of forms of community-control-service mechanisms. They include age, sex, education, party, locationurban or rural - and two dummy variables for region: Hubei and Wuhan; the reference group is other regions. Age was measured in years. Sex was measured by male $(=1)$ and female $(=0)$. Education was measured by the highest degree completed or was studying for at the interview time. The answer categories were elementary or less $(=1)$, junior high $(=2)$, high school $(=3)$, technical school $(=4)$, 3-year college $(=5)$, bachelor's (4-year) degree $(=6)$, and graduate school (=7). Party was measured by whether a respondent was the Communist Party member with yes $=1$ and no $=0$. Location was measured by whether a respondent came from an urban area or rural area. The two dummy variables are Hubei $(=1)$ and Wuhan $(=1)$.

\section{Findings}

Table 1 is constructed to meet the first goal of this study: investigate the prevalence of semiformal organizations participating in social control and service during the COVID-19 lockdown. The table is based on the data from the respondents' answers to this question: "During the COVID-19 lockdown period, who participated in the following activities: checkpoint inspection, health screening, food supplies, drug supplies, sanitization, and information distribution." The choices included residents' or village committee, government agencies or officers, community police or police officers, volunteers, regular citizens, and no action. The respondents could make multiple choices for each activity item. In this survey, volunteers were those who registered with a residents' committee in urban areas or a village committee in rural areas to volunteer their time to help the community control and service activities. Regular citizens refer to any citizens who voluntarily helped the community control and service activities but did not register with the community.

Visual inspection of Table 1 revealed several points. First, relative to other activity items, demand for food and drug supplies via community was lower. This finding makes sense because only a small portion of people need drugs. In addition, citizens who were not infected by the virus or their neighbors in a same multi-story building who were not infected by the virus were usually allowed to go out to buy life necessities by themselves, though they were limited to one person per family at certain time periods.

Second, community (resident's or village) committee had the highest participation in all the activities. This finding is not surprising. According to China's Residents' Committee Act of 1989, a community is a self-governing unit. Each community has a residents' or village committee, in which members are local citizens and elected by local citizens and approved by 
Table 1 During the lockdown, who participated in the following activities (can choose more than one)

\begin{tabular}{lllllll}
\hline Activity & $\begin{array}{l}\text { Residents } \\
\text { or village } \\
\text { committee }\end{array}$ & $\begin{array}{l}\text { Government } \\
\text { agencies or } \\
\text { officials }\end{array}$ & $\begin{array}{l}\text { Community } \\
\text { police }\end{array}$ & Volunteer & $\begin{array}{l}\text { Regular } \\
\text { citizens }\end{array}$ & None \\
\hline $\begin{array}{l}\text { 1. Checkpoint } \\
\text { inspection }\end{array}$ & $491(77.69 \%)$ & $282(44.62 \%)$ & $184(29.11 \%)$ & $347(54.91 \%)$ & $169(26.74 \%)$ & $39(6.17 \%)$ \\
$\begin{array}{l}\text { 2. Health } \\
\text { screening }\end{array}$ & $484(76.58 \%)$ & $309(48.89 \%)$ & $165(26.11 \%)$ & $272(43.04 \%)$ & $95(15.03 \%)$ & $47(7.44 \%)$ \\
$\begin{array}{l}\text { 3. Food supply } \\
\text { 4. Drug shopping }\end{array}$ & $369(58.39 \%)$ & $171(27.06 \%)$ & $56(8.86 \%)$ & $304(48.1 \%)$ & $201(31.8 \%)$ & $115(18.2 \%)$ \\
$\begin{array}{l}\text { 5. Community } \\
\text { sanitization }\end{array}$ & $454(71.84 \%)$ & $225(35.6 \%)$ & $97(15.35 \%)$ & $259(40.98 \%)$ & $143(22.63 \%)$ & $68(10.76 \%)$ \\
$\begin{array}{l}\text { 6. COVID-19 } \\
\text { information } \\
\text { distribution }\end{array}$ & $491(77.69 \%)$ & $337(53.32 \%)$ & $136(21.52 \%)$ & $184(29.11 \%)$ & $81(12.82 \%)$ & $51(8.07 \%)$ \\
\hline
\end{tabular}

the government (Jiang et al. 2010b). The committee has many neighborhood functions, including but not limited to "distributing and promoting laws and policies from the central government and local government, settling disputes, assisting the local police department to maintain public order, ..., household registration, local sanitation and cleanliness activities, encouraging residents to practice birth control, and a variety of other services to the local residents, such as establishing senior centers" (Jiang et al. 2010b, p. 462). During the COVID19 lockdown, the residents'/village committee was instructed by the government to participate in the activities listed in Table 1.

Third, overall, volunteers had the second highest participation in the Table 1 activities. China is a collective society, and things or activities are usually organized and done by the local community and government. However, during these lockdown times, many people volunteered their time, resources, and vehicles to help needy people in the community. This voluntary outpouring was a particularly good thing happening in this challenging time. Table 1 showed that volunteers actively participated in all activities except distributing the healthrelated information. A relatively low level of participation in the activity is understandable because this information is more likely from the government. The government mobilized to address the COVID-19 health crisis at multiple levels, most prominently flying in thousands of nurses and doctors from around China to Wuhan and other Hubei cities (Xinhua News 2020).

Fourth and the last, the participation of community police officers in Table 1 activities was not high. There were at least two reasons behind the low level of the participation. First, a community usually has one officer so their participation was not easily observed. Second, the officer's major role is to assist the community committee to maintain community order. During the lockdown, outdoor activities were reduced to a minimum, and as a result, deviant or criminal behavior was also greatly decreased. Thus, the officer's social control action was also lessened.

In sum, formal organizations, government agencies and police, the semiformal organizations, residents' committee in urban areas and village committee in rural areas, and informal groups or individuals, volunteers, and regular citizens, all participated in community control and service. Semiformal organizations had the highest level of participation during the lockdown period.

Table 2 is constructed to meet the second purpose of the study: investigate the importance of semiformal organizations in social control and service, compared to formal organizations 
Table 2 Summary of the importance ranking of each of the following organizations/groups/individuals in six community activities during the lockdown

\begin{tabular}{llllll}
\hline Activity & $\begin{array}{l}\text { Residents or } \\
\text { village } \\
\text { committee }\end{array}$ & $\begin{array}{l}\text { Government } \\
\text { agencies or } \\
\text { officials }\end{array}$ & Community police & Volunteer & Regular citizens \\
\hline 1. Checkpoint inspection & 4.60 & 4.46 & 4.46 & 4.31 & 3.80 \\
2. Health screening & 4.60 & 4.51 & 4.37 & 4.19 & 3.87 \\
3. Food supply & 4.31 & 4.08 & 3.81 & 4.39 & 3.92 \\
4. Drug shopping & 4.30 & 4.11 & 3.83 & 4.34 & 3.79 \\
5. Community sanitization & 4.51 & 4.31 & 3.96 & 4.16 & 3.90 \\
6. COVID-19 & 4.52 & 4.49 & 4.14 & 4.07 & 3.85 \\
$\quad$ information & & & & & \\
$\quad$ distribution & & & & & \\
\hline
\end{tabular}

Each of the actors in this table was ranked in terms of their importance in the six activities. The answer categories concerning the importance are not important at all $(=1)$, not important $(=2)$, between not important and important (=3), important $(=4)$, and very important $(=5)$

and informal groups. The table presents the perceived importance of five types of actors in the six activities. Consistent with the level of participation in the activities, the importance of the community committee was the highest while that of regular citizens was the lowest. In addition, community police officers were ranked relatively high in mandatory controlling items such as a checkpoint inspection and health screening and low in-service items such as helping shop for necessities and medicine. Next, the importance of government agencies or officers was relatively low in shopping for necessities and medicine and relatively high in other items such as health information distribution and health screening. This finding makes sense because the governmental role at the community level was more focused on directing and supervising action implementation rather than specific action. Although the government sent one or more officials to each community, their visibility to citizens was low. In contrast with government agencies or officers, the importance of volunteers in shopping for necessities and medicine was very high. Their high participation or action in these activities may be the reason behind this. Examining Table 2, government services acted as the superstructure providing guidance with the volunteers acted informally to meet daily needs.

The findings from Table 2 confirmed the importance of semiformal organizations in maintaining community order and providing community service during the lockdown period. The reported importance of semiformal organizations is higher than that of formal organizations and informal groups.

Tables 3, 4, and 5 meet the third purpose of the study: discover the predictors of the views of forms of social control and service. Table 3 presents the descriptive statistics of the dependent and independent variables in this study. The mean score for each dependent variable in the table was created from the simple summation of scores in the six community activity items. As revealed in Table 2, the summarized mean scores in Table 3 confirmed that community had the highest score, government the second, volunteer the third, police the fourth, and citizen the last. For the independent variables, about $33 \%$ of the respondents were members of the Chinese Communist Party. Almost $50 \%$ of the respondents were from rural areas while the other $50 \%$ from urban areas. More females $(56 \%)$ participated in the survey. The mean age of the respondents was approximately 26. Most respondents had a bachelor's degree or were studying at a 4-year college.

Table 4 presents the results from bivariate regression analyses of all independent and dependent variables. Table 5 shows the findings from multiple regression analyses of the 
Table 3 Descriptive statistics of independent and dependent variables

\begin{tabular}{|c|c|c|c|c|}
\hline & Minimum & Maximum & Mean & Standard deviation \\
\hline \multicolumn{5}{|l|}{ Dependent variable } \\
\hline Community & 6 & 30 & 27.08 & 3.74 \\
\hline Government & 6 & 30 & 26.08 & 4.36 \\
\hline Police & 6 & 30 & 24.72 & 5.10 \\
\hline Volunteer & 6 & 30 & 25.57 & 4.42 \\
\hline Citizen & 6 & 30 & 23.28 & 5.58 \\
\hline \multicolumn{5}{|l|}{ Independent variable } \\
\hline Party $(=1)$ & 0 & 1 & .33 & .47 \\
\hline City $(=1)$ & 0 & 1 & .49 & .50 \\
\hline Hubei (=1) & 0 & 1 & .40 & .49 \\
\hline Wuhan $(=1)$ & 0 & 1 & .30 & .46 \\
\hline Gender $($ male $=1)$ & 0 & 1 & .44 & .50 \\
\hline Age & 18 & 63 & 25.99 & 7.72 \\
\hline Education & 1 & 7 & 5.83 & 1.14 \\
\hline
\end{tabular}

effect of all the independent variables on each dependent variable. Several significant relationships in Table 4 disappeared in Table 5.

Visual inspection of Tables 4 and 5 shows that education is the strongest predictor of the views of all the five control and service mechanisms: communities, governments, police, volunteers, and regular citizens. It is the only predictor that is statistically significant for all the five control and service mechanisms. One possible reason behind the finding is that people who are more educated are more critical and have higher expectations about the role each control and service mechanism should play. Thus, relative to those with lower education, the respondents with higher education were more likely to give control and service mechanisms lower rankings of their level of involvement in control and service activities.

Next, age is a significant predictor for the views of government agencies/officials and community policing officers. Furthermore, younger people had more favorable views. This is surprising. The findings are neither consistent with the expectations in this study nor the

Table 4 Bivariate regression estimates with five dependent variables

\begin{tabular}{|c|c|c|c|c|c|c|c|c|c|c|}
\hline \multirow{3}{*}{$\begin{array}{l}\text { Independent } \\
\text { variable }\end{array}$} & \multicolumn{10}{|c|}{ Dependent variables } \\
\hline & \multicolumn{2}{|c|}{$\begin{array}{l}\text { Community } \\
\text { committee }\end{array}$} & \multicolumn{2}{|c|}{ Government } & \multicolumn{2}{|c|}{$\begin{array}{l}\text { Community } \\
\text { police }\end{array}$} & \multicolumn{2}{|c|}{ Volunteer } & \multicolumn{2}{|c|}{ Regular citizen } \\
\hline & $B$ & s.e. & $b$ & s.e. & $b$ & s.e. & $b$ & s.e. & $b$ & s.e. \\
\hline Party & -.624 & .359 & -1.605 & $.381 * * *$ & -2.811 & $.461^{* * *}$ & -.620 & .395 & -2.327 & $.520 * * *$ \\
\hline City & -.343 & .312 & -.930 & $.363 * *$ & .685 & .445 & -.120 & .374 & -1.337 & $.491 * *$ \\
\hline Hubei & .238 & .385 & .368 & .449 & .792 & .543 & 1.192 & $.456^{* *}$ & 1.182 & $.597 *$ \\
\hline Wuhan & -.073 & .410 & -.323 & .477 & -.784 & .582 & 1.247 & $.488 * *$ & .235 & .655 \\
\hline Sex & .400 & .314 & .167 & .368 & -.218 & .448 & .519 & .376 & .247 & .498 \\
\hline Age & -.021 & .020 & -.090 & $.023 * * *$ & -.162 & $.028 * * *$ & .007 & .023 & -.085 & $.031 * *$ \\
\hline Education & -.398 & $.135^{* * *}$ & -.951 & $.155^{* * *}$ & -1.411 & $.186^{* * *}$ & -.881 & $.162 * * *$ & -1.178 & $.208 * * *$ \\
\hline
\end{tabular}

(1) The two dummy variables Hubei and Wuhan were entered into the regression model together. (2) Results from independent $t$ tests for comparing two means showed the same patterns as in this table regarding whether a relationship between two variables (one nominal independent variable with importance view scores) is statistically significant

$* p<.05, * * p<.01, * * * p<.005$ 
Table 5 Multiple regression estimates with five dependent variables

\begin{tabular}{|c|c|c|c|c|c|c|c|c|c|c|}
\hline \multirow{3}{*}{$\begin{array}{l}\text { Independent } \\
\text { variable }\end{array}$} & \multicolumn{10}{|c|}{ Dependent variables } \\
\hline & \multicolumn{2}{|c|}{$\begin{array}{l}\text { Community } \\
\text { committee }\end{array}$} & \multicolumn{2}{|c|}{ Government } & \multicolumn{2}{|c|}{$\begin{array}{l}\text { Community } \\
\text { police }\end{array}$} & \multicolumn{2}{|c|}{ Volunteer } & \multicolumn{2}{|c|}{ Regular citizen } \\
\hline & $B$ & s.e. & $b$ & s.e. & $b$ & s.e. & $b$ & s.e. & $b$ & s.e. \\
\hline Party & -.203 & .407 & -.184 & .461 & -.570 & .555 & .212 & .480 & -.934 & .636 \\
\hline City & -.127 & .363 & -.409 & .414 & .712 & .484 & .036 & .426 & -.749 & .559 \\
\hline Hubei & .093 & .393 & .003 & .448 & .554 & .524 & .977 & $.458 *$ & .649 & .596 \\
\hline Wuhan & -.045 & .446 & .025 & .502 & -.445 & .590 & .948 & .523 & .732 & .692 \\
\hline Sex & .405 & .315 & .207 & .356 & -.139 & .418 & .400 & .369 & .202 & .484 \\
\hline Age & -.006 & .023 & -.061 & $.026^{*}$ & -.117 & $.031 * * *$ & .011 & .027 & -.038 & .035 \\
\hline Education & -.342 & $.154 *$ & -.829 & $.174 * * *$ & -1.214 & $.205 * * *$ & -.893 & $.184 * * *$ & -.911 & $.234 * * *$ \\
\hline
\end{tabular}

$* p<.05, * * p<.01, * * * p<.005$

findings in the previous studies of formal and informal control (Jiang et al. 2014; Jiang et al. 2010b; Jiang et al. 2010a). Do these findings suggest that younger people have more trust and confidence in government in community control and service? A further examination reveals that the mean age of the respondents is about 26. Many of them have grown up at the time when China's economy developed quickly and has improving international visibility. Relative to older people, they may be fortunate with no experiences of economic hardship in their life. They may be still in school and have been educated to hold a positive view of the government and China. Acknowledging different lived experiences, it is worth further examining the linkages between respondents' ages and views of control mechanisms and support for government policies.

Another surprising finding from Table 4 is that party membership was negatively associated with the importance views of government and police. That is, the Communist Party members ranked the importance of government and police in maintaining community order and providing community service during the lockdown lower than non-party members did. In order to explore the reason behind these unexpected findings, this study used the forward selection method to control other variables in multiple regression analyses or multi-factor ANOVA tests. Results (not shown here but available upon to request) reveal that when education was controlled for, the relationships between party and the views of government and the views of police disappeared. These findings suggest that party members had less favorable views on the importance of government and police because they were more educated. The educated party members may recognize that disasters tend to disrupt bureaucratic goals and tasks when predictable social harmony and stable growth have been put forward as party goals to the public (Irwin and Willis, 2013).

Table 4 also shows that respondents from urban areas ranked the importance of government and regular citizens in community control and service lower than those from rural areas. A further examination (results not shown here but available upon to request) reveals that when education was controlled for, city dwelling became statistically insignificant for government, and when both education and age were controlled for, city dwelling was no longer a predictor of the views of regular citizens. A further examination also showed that education and urban life intervened in the relationship between Wuhan and volunteers and partially explains the relationship between Hubei Province and volunteers. Furthermore, when the variables education and city were controlled for, the relationship between Wuhan and volunteers disappeared, 
while the strength of the relationship between Hubei and volunteers was reduced. Education mediates the relationship between Hubei Province and regular citizens.

\section{Conclusion}

Findings reported in the last section are constrained; first, the sample used in this study was not randomly selected and findings cannot be generalized to the larger population with a known error, and second, due to the COVID-19 pandemic, people in China had limited interpersonal interactions during the survey time period. The online questionnaire survey and interviews were important methods to collect this purposive data while the response to COVID-19 was still ongoing. Internet access and a certain education level were required to participate in the surveys/interviews. As a result, the respondents surveyed in this study are younger and more educated than the general population. In addition, the proportion of the Chinese Communist Party members (33\%) in this study is higher than that (8\%) of the general population aging 18 and older, suggesting that Party members, not intentionally, were oversampled. These sampling biases can result in the over- or underestimation of the corresponding population values. In this regard, the nature of this study is exploratory. Findings from this study are preliminary rather than conclusive.

Nonetheless, this study contributes to the research on forms of social control and social governance in several ways. This is the first to quantitatively investigate the prevalence of formal, informal, and semiformal control and control mechanisms simultaneously. Thus, the study was able to provide us with comparative results of the participation level of each organization or group and their levels of control employed in maintaining community order and providing community service during the unique COVID-19 lockdown conceived in China. Results from this study provide complementary evidence that semiformal organizations and control are prevalent in China's social control and governance (Jiang et al. 2019). This study on the COVID-19 response in China is also the first to quantitatively evaluate the importance of formal, informal, and semiformal control and control mechanisms in maintaining community order and providing community service. The findings regarding the conceived importance allow us to not only compare the relative importance of each form of social control and service in China but also eventually find commonalities and differences with other nations in terms of COVID-19 control mechanism using the survey methods described herein. The findings regarding the conceived importance also help us understand why semiformal organizations such as residents' committee and village committee play such a prevalent part in China's social control and services.

Finally, this study found that education and age are the two major predictors of the views on the importance of formal, informal, and semiformal control and control mechanisms. The findings confirmed the expectation that more educated people were more critical and expected more from all forms of control mechanisms in social control and service so they ranked the importance of all forms of control mechanisms lower than less educated people. Findings from this study are inconsistent with our expectation that older people are more likely to have a favorable ranking of the importance of government agencies/officials and police in social control and service. Some possible reasons are explored in the "Findings" section, but more research is required to examine the age-importance view linkage. With a current focus fixed on the COVID-19 pandemic, these findings from citizen respondents in China, though an important contribution, are preliminary, and more relevant research is needed in the future. 


\section{Compliance with Ethical Standards}

Conflict of Interest The authors declare that they have no conflict of interest.

Ethical Approval Yes

Informed Consent Yes

\section{References}

Black, D. (1976). The behavior of law. New York: Academic Press.

Black, D. (1993). The social structure of right and wrong. New York: Academic.

Caixin (2020). 中国内地31省份全部启动突发公共卫生事件一级响应 (Thirty one provinces or equivalents in mainland China lunched a Class I to Public Health Emergency. Archived from the original on 2 February 2020. Accessed on May 8, 2020.

Chen, X. (2004). Social and legal control in China: a comparative perspective. International Journal of Offender Therapy and Comparative Criminology, 48, 523-536.

China CDC (2020). Notice of tightening the prevention and control Covid-19. http://www.nhc.gov.cn/jkj/s3577 /202001/dd1e502534004a8d88b6a10f329a3369.shtml, .

Friday, P. C. (1998). Crime and crime prevention in China: a challenge to the development-crime nexus. Journal of Contemporary Criminal Justice, 14, 296-314.

Gilligan, C. (1982). In a different voice: Psychological theory and women's development. Cambridge, MA: Harvard University Press.

Han, T. (2020). 武汉时间: 从专家组抵达到封城的谜之20天 (Wuhan 20 days) https://news.sina.cn/gn/2020-02-07 /detail-iimxxste9632689.d.html?vt=4\&pos=108, .

Huang, P. C. C. (1993a). Between informal mediation and formal adjudication: the third realm of Qing civil justice. Modern China, 19, 251-298.

Huang, P. C. C. (1993b). "Public sphere"/“civil society" in China? The third realm between state and society. Modern China, 19, 216-240.

Huang, P. C. C. (2008). Centralized minimalism: Semiformal governance by quasi officials and dispute resolution in China. Modem China, 34, 9-35.

Huang, P. C. C. (2010). Chinese civil justice, past and present. New York: Roman \& Littlefield Publishers, Inc..

Hubei.gov (2020). Notice of further tightening restrictions amid the COVID-19 crisis. http://news.xhby. net/zt/zzccfkyq/yw/202002/t20200216 6514009.shtml. .

Irwin, D., \& Willis, C. (2013). Success or sorrow: the paradoxical view of crime control campaigns in China. International Journal of Comparative and Applied Criminal Justice, 38(1), 63-81.

Irwin, D., Zhang, D., \& Wang, S. (2016). China's social transformation and the development of rural community corrections. In J. Donnermeyer (Ed.), The Routledge International Handbook of Rural Criminology. NY: Routledge.

Jiang, S. (2014). Social and crime control with Chinese characteristics. In Liqun Cao, Ivan Sun and Bill Hebenton (Eds.), The Handbook of Chinese Criminology, pp. 27-36. Routledge Publishers.

Jiang, S., \& Lambert, E. (2009). Views of formal and informal crime control and their correlates in China. International Criminal Justice Review, 19, 5-24.

Jiang, S., Lambert, E., \& Wang, J. (2007). Correlates of formal and informal social/crime control in China. Journal of Criminal Justice, 35, 261-271.

Jiang, S., Lambert, E., \& Jenkins, M. (2010a). East meets West: an empirical comparison of formal and informal crime control among Chinese and the U.S. students. International Journal of Offender Therapy and Comparative Criminology, 54, 264-284.

Jiang, S., Wang, J., \& Lambert, E. (2010b). Correlates of informal social control in Guangzhou, China neighborhoods. Journal of Criminal Justice, 38, 460-469.

Jiang, S., Lambert, E., Saito, T., \& Hara, J. (2012). University students' views of formal and informal control in Japan: an exploratory study. Asian Journal of Criminology, 7, 137-152.

Jiang, S., Lambert, E., Liu, J., \& Saito, T. (2014). Formal and informal control inChina, Japan and the U.S. Journal of Criminal Justice, 42, 36-44.

Jiang, S., Land, K., \& Wang, J. (2013). Social ties, collective efficacy and perceived neighborhood property crime in Guangzhou, China. Asian Journal of Criminology, 8, 207-223. 
Jiang, S., Zhang, D., Jin, X., Xiang, D., Greenleaf, R., Liu, J., \& Xu, N. (2015). Semiformal crime control and semiformal organizations in China: an empirical demonstration from Chinese community corrections. Asian Journal of Criminology, 10, 287-302.

Jiang, S., Zhang, D., \& Zhai, J. (2019). Semiformal control: a paradigm from Chinese society. Journal of Jiansu Police Institute, 34, 100-110.

Lambert, E., Jiang, S., Wang, J., \& Tucker, K. (2007). A preliminary study of gender differences on views of crime and punishment among Chinese college students. International Criminal Justice Review, 17, $108-124$.

Lambert, E., Jaishankar, K., Jiang, S., Pasupuleti, S., \& Bhimarasetty, J. V. (2012a). Correlates of formal and informal social control on crime prevention: an exploratory study among university students, Andhra Pradesh, India. Asian Journal of Criminology, 7, 239-250.

Lambert, E., Khondaker, M. I., Elechi, O. O., Jiang, S., \& Baker, D. (2012b). Formal and informal crime control views in Bangladesh and the United States. Journal of Ethnicity in Criminal Justice, 10, 199-222.

Liu, J. H., Zhang, L. N., \& Messner, S. F. (2001). Crime and social control in a changing China. Westport: Greenwood Press.

Mao, S., Ma, N., Lan, Z., \& Chen, J. (2020). 武汉解封 (Wuhan lifted the lockdown order)! https://news.sina.com. $\mathrm{cn} / \mathrm{c} / 2020-04-08 /$ doc-iimxyqwa5622908.shtml. .

Rojek, D. G. (2001). Chinese social control: From shaming and reintegration to "getting rich is glorious." In J. Liu, L. Zhang, \& S. F. Messner (Eds.), Crime and social control in a changing China (pp. 89-103). Westport, CT: Greenwood Press.

Rose, D. R., \& Clear, T. R. (1998). Incarceration, social capital, and crime: implications for social disorganization theory. Criminology, 36, 441-479.

Rosenbaum, D. S. (1988). Community crime prevention: a review and synthesis of the literature. Justice Quarterly, 5, 323-395.

Sampson, R. J., Raudenbush, S. W., \& Earls, F. (1997). Neighborhoods and violent crime: a multilevel study of collective efficacy. Science, 277, 918-924.

Sun, I., Wu, Y., Hu, R., \& Farmer, A. (2017). Procedural justice, legitimacy, and public cooperation with police: does western wisdom hold in China? Journal of Research in Crime and Delinquency, 54, 454- 478.

Tang, B. (2020). Grid governance in China's urban middle-class neighborhoods. The China Quarterly, 241, 4361.

Troyer, R. J. (1989). Chinese social organizations. In R. J. Troyer, J. P. Clark, \& D. G. Rojek (Eds.), Social control in the People's Republic of China (pp. 26-33). New York: Praeger.

Xinhua News (2020). How does China combat \#coronavirus: More than 20,000 medics across the country came to Wuhan. http://www.xinhuanet.com/english/2020-02/17/c_138791902.htm.

Xiong, X. (1999). Criminal justice systems in China. Beijing: China's Law Press.

Zhang, L., Zhou, D., Messner, S. F., Liska, A. E., Krohn, M. D., Liu, J., \& Lu, Z. (1996). Crime prevention in a communitarian society: Bang-jiao and Tiao-jie in the People's Republic of China. Justice Quarterly, 13, $199-222$.

Zhang, L., Messner, S. F., \& Liu, J. (2007). Bicycle-theft victimization in contemporary urban China: a multilevel assessment of risk and protective factors. Journal of Research in Crime and Delinquency, 44, $406-426$.

Publisher's Note Springer Nature remains neutral with regard to jurisdictional claims in published maps and institutional affiliations. 